\section{Surveillance of Salmonid Viruses Especially Targeting Infectious Salmon Anemia Virus in Japan}

\author{
Hisae Kasai*, Shuhei Iwawaki \\ and Mamoru Yoshimizu \\ Faculty of Fisheries Sciences, Hokkaido University, \\ Hokkaido 041-8611, Japan
}

(Received June 24, 2009)
Oncorhynchus kisutch ${ }^{5)}$ and rainbow trout 0. mykiss $^{15)}$. However, natural outbreaks of ISA has been limited to Atlantic salmon ${ }^{16)}$.

Dannevig et al. ${ }^{17)}$ succeeded in the propagation of ISAV using SHK-1 cell line derived from the head kidney of Atlantic salmon, and later it was revealed that ISAV propagation was possible using ASK from Atlantic salmon kidney and some other salmonid cell lines ${ }^{18)}$. ASK cell line is widely used for culture isolation of ISAV due to the instruction from the OIE reference laboratory of ISA ${ }^{19)}$. Nucleotide sequence of ISAV genomes has been analyzed and PCR primers have been developed for detection and identification of $I S A V^{18)}$.

Although salmonid fish species susceptible to ISAV are cultured in Japan, outbreaks have not been reported and ISAV was not isolated in surveillance of salmonid fish viruses using CHSE-214 and other salmonid fish cell lines ${ }^{20,21)}$. However CHSE-214 and other salmonid fish cell lines have low sensitivity to ISAV. Thus, in the present study we conducted virus isolation from returning and cultured salmonid fish species from 2005 to 2007 in Japan with ASK and ASE cell lines, mainly targeting ISAV.

\section{Materials and Methods}

Virus isolation

A total of 5,967 ovarian fluids of eight fish species including chum salmon $O$. keta, rainbow trout, masu salmon O. masou, amago salmon O. rhodurus, coho salmon, pink salmon $O$. gorbuscha, sockeye salmon $O$. nerka and iwana (= char) Salveninus pluvius, were collected in 18 prefectures from 2005 to 2007 (Fig. 1 and Table 1). Chum, pink, sockeye and masu salmon were obtained at catching stations near river mouths located in Hokkaido, Iwate, Yamagata, Niigata and Toyama Prefectures in Japan, and reared in ponds of their respective hatcheries until they matured. Rainbow trout, amago salmon, coho salmon, yamame (= land-locked masu salmon) and iwana were obtained at aquaculture farms in Hokkaido, Iwate, Miyagi, Akita, Yamagata, Tochigi, Gunma, Ishikawa, Yamanashi, Nagano, Gifu, Shizuoka, Aichi, Shiga, Okayama, Tokushima, Ehime and Miyazaki prefectures, Japan (Fig. 1).

Sixty samples of ovarian fluids were collected from each fish according to the method of Yoshimizu et al. ${ }^{22}$. Briefly, a sterilized pipette tip was inserted via the urogenital opening into the ovary of matured females to obtain approximately $1 \mathrm{~mL}$ of ovarian fluids. The ovarian fluids were immediately mixed with the same volume of antibiotic solution (anti-ink: 1,000 IU/mL penicillin G (Sigma), $1.0 \mathrm{mg} / \mathrm{mL}$ streptomycin (Sigma) and 800 $\mathrm{U} / \mathrm{mL}$ mycostatin in Hanks' balanced salt solution), and were transported with ice to the laboratory. After overnight incubation at $4^{\circ} \mathrm{C}$, the ovarian fluids were inocu-

\footnotetext{
* Corresponding author

E-mail: hisae@fish.hokudai.ac.jp
} 


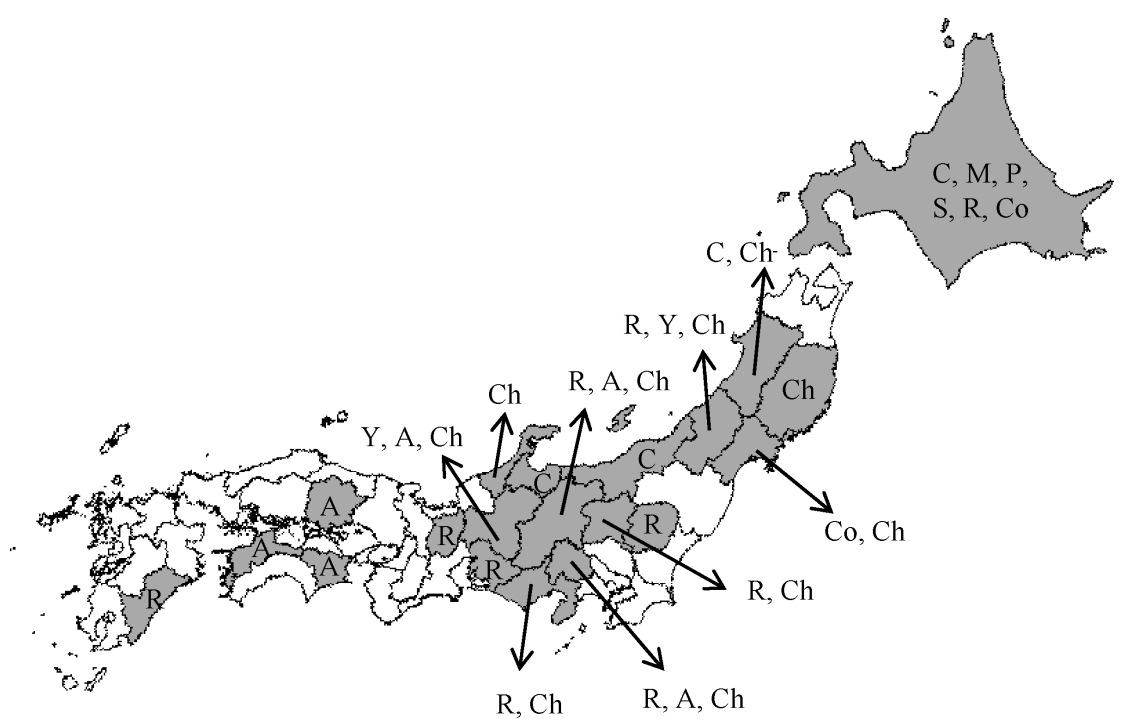

Fig. 1. Sampling areas of fish ovarian fluids for virus isolation. C: chum salmon, M: masu salmon, P: pink salmon, S: sockeye salmon, $\mathrm{R}$ : rainbow trout, $\mathrm{Y}$ : yamame, $\mathrm{A}$ : amago salmon, $\mathrm{Co}$ : coho salmon, and $\mathrm{Ch}$ : char.

Table 1. Virus isolation from fish ovarian fluids of salmonid fishes $(n=5,967)$

\begin{tabular}{|c|c|c|c|c|c|c|c|c|c|c|}
\hline \multirow{3}{*}{ Fish species } & \multirow[b]{3}{*}{$\mathrm{n}$} & \multicolumn{9}{|c|}{ Isolated / Tested } \\
\hline & & \multicolumn{3}{|c|}{ ISAV } & \multicolumn{3}{|c|}{ IHNV } & \multicolumn{3}{|c|}{ IPNV } \\
\hline & & 2005 & 2006 & 2007 & 2005 & 2006 & 2007 & 2005 & 2006 & 2007 \\
\hline \multicolumn{11}{|l|}{ Reterning fishes } \\
\hline Chum salmon & 2,100 & $0 / 480$ & $0 / 840$ & $0 / 780$ & $0 / 480$ & $0 / 840$ & $0 / 780$ & $0 / 480$ & $0 / 840$ & $0 / 780$ \\
\hline Masu salmon & 571 & $0 / 111$ & $0 / 180$ & $0 / 280$ & $0 / 111$ & $0 / 180$ & $1 / 280$ & $0 / 111$ & $0 / 180$ & $0 / 280$ \\
\hline Pink salmon & 180 & $0 / 60$ & $0 / 60$ & $0 / 60$ & $0 / 60$ & $0 / 60$ & $0 / 60$ & $0 / 60$ & $0 / 60$ & $0 / 60$ \\
\hline Sockeye salmon & 115 & - & $0 / 55$ & $0 / 60$ & - & $0 / 55$ & $0 / 60$ & - & $0 / 55$ & $0 / 60$ \\
\hline \multicolumn{11}{|l|}{ Cultured fishes } \\
\hline Rainbow trout & 1,573 & $0 / 480$ & $0 / 556$ & $0 / 537$ & $44 / 480$ & $44 / 556$ & $9 / 537$ & $0 / 480$ & $0 / 556$ & $0 / 537$ \\
\hline Yamame & 131 & - & $0 / 11$ & $0 / 120$ & - & $0 / 11$ & $2 / 120$ & - & $0 / 11$ & $3 / 120$ \\
\hline Amago salmon & 482 & - & $0 / 180$ & $0 / 302$ & - & $14 / 180$ & $2 / 302$ & - & $0 / 180$ & $4 / 302$ \\
\hline Coho salmon & 236 & $0 / 60$ & $0 / 56$ & $0 / 120$ & $0 / 60$ & $0 / 56$ & $0 / 120$ & $0 / 60$ & $0 / 56$ & $0 / 120$ \\
\hline Char & 579 & $0 / 60$ & - & $0 / 519$ & $0 / 60$ & - & $0 / 519$ & $0 / 60$ & - & $7 / 519$ \\
\hline Total & 5,967 & $0 / 1,251$ & $0 / 1,938$ & $0 / 2,778$ & $44 / 1,251$ & $58 / 1,938$ & $14 / 2,778$ & $0 / 1,251$ & $0 / 1,938$ & $14 / 2,778$ \\
\hline
\end{tabular}

lated onto ASK or ASE cells seeded in 48-well culture plates, previously maintained at $15^{\circ} \mathrm{C}$ with $\mathrm{L}-15$ medium (Gibco) supplemented with $10 \%$ fetal bovine serum, 100 $\mathrm{IU} / \mathrm{mL}$ penicillin $\mathrm{G}$ (Sigma) and $100 \mu \mathrm{g} / \mathrm{mL}$ streptomycin (Sigma). The inoculated cells were cultured at $15^{\circ} \mathrm{C}$ for two weeks to monitor appearance of cytopathic effect (CPE). A portion of culture fluids of the inoculated cells showing CPE was subcultured with the same cell line for another two weeks to confirm the results.

\section{Identification of isolated viruses}

The isolated viruses were identified by RT-PCR with three primer sets targeting ISAV genome segment 8, IHNV G gene or IPNV NS/VP3 junction region, respectively. The first primer set for ISAV was FA-3 (5'-GAA GAG TCA GGA TGC CAA GAC G-3') and RA3 (5'-GAA GTC GAT GAA CTG CAG CGA-3' $)^{18)}$; the second one for IHNV was ID3 (5'-GAT TGG AGA TTT
TAT CAA CA-3') and ID4 (5'-CTC TGG ACA AGC TCT CCA AGG-3' $)^{23)}$; and the third one for IPNV was P1 (5'AGA GAT CAC TGA CTT CAC AAG TGA C-3') and P2 (5'-TGT GCA CCA CAG GAA AGA TGA CTC-3' $)^{24)}$. Target region of the viral genome RNAs were transcribed to cDNA at $42^{\circ} \mathrm{C}$ for $30 \mathrm{~min}$ and amplified by 35 cycles of the following reaction; $95^{\circ} \mathrm{C}$ for $1 \mathrm{~min}$, primerspecific temperature $\left(59^{\circ} \mathrm{C}, 56^{\circ} \mathrm{C}\right.$ and $50^{\circ} \mathrm{C}$ for ISAV, IHNV and IPNV, respectively) for $1 \mathrm{~min}$ and $72^{\circ} \mathrm{C}$ for 1 $\mathrm{min}$. The amplified products were analyzed by $1.5 \%$ agarose gel electrophoresis. For PCR negative isolates, indirect fluorescent antibody test (IFAT) was performed on ASK cells showing CPE using polyclonal antibodies against IHNV and IPNV. Briefly, The cells were exposed to anti-IHNV and IPNV sera in a moist chamber, washed, and then exposed to anti-rabbit Ig swine Ig conjugated with FITC (DAKO) (diluted 1:50); both incubations took place at $37^{\circ} \mathrm{C}$ for $30 \mathrm{~min}$. 


\section{Results and Discussion}

In the present surveillance from 2005 to 2007, no virus was isolated from chum salmon $(n=2,100)$, coho salmon $(n=236)$, pink salmon $(n=180)$ and sockeye salmon $(n=115)$ (Table 1$)$. In rainbow trout, virus was isolated from 44 out of 480 samples $(9.2 \%)$ in 2005,44 out of 556 samples (7.9\%) in 2006 and nine out of 537 samples $(1.7 \%)$, and all of them were identified as IHNV by RT-PCR or IFAT. In masu salmon $(n=571)$ and yamame $(n=131)$, no virus was isolated in 2005 and 2006 while IHNV from one masu salmon and from two yamae and IPNV from three yamame were isolated in 2007. Sixteen isolates of IHNV and four isolates of IPNV were obtained from amago salmon between 2006 and 2007 while seven isolates of IPNV were obtained from char in 2007. In the present surveillance, no ISAV was isolated from eight salmonid fish species $(\mathrm{n}=$ 5,967 ), while IHNV was isolated in 11 and IPNV in nine prefectures. Detection rate of IHNV and IPNV in each prefecture were $1.7-50 \%$ and $1.7-6.7 \%$, respectively.

In this study we used ovarian fluids for culture isolation of ISAV because it was very convenient to collect a large number of samples, and it is known that ISAV is present in ovarian fluids of ISA-affected brood stocks ${ }^{25)}$. Furthermore, in our experience, sensitivity of virus isolation from ovarian fluids was as good as that from fish tissues, and higher than direct detection by PCR. In our previous surveillance with CHSE-214 and other salmonid fish cell lines, no ISAV was isolated in Japan. This was confirmed in the present study with ASK and ASE cell lines which are more sensitive to ISAV than CHSE214 cell line ${ }^{26)}$. Therefore, we would strongly speculate that Japanese environment for salmonid fishes is still ISAV-free.

It was reported that ISAV was not detected in fish hatched from eggs disinfected with iodine even if those eggs were obtained from ISAV-contaminated brood stocks $^{25)}$, demonstrating that ISAV, being enveloped, is easily inactivated by iodine. Japan has imported eyed eggs of Atlantic salmon and other salmonid fishes, but which has been all disinfected with iodine since 1990 . It is considered that the countermeasure for general prevention of fish viruses is useful and important to maintain ISAV-free environment in Japan.

\section{Acknowledgements}

We thank the Japan Fisheries Resource Conservation Association and all prefectural fisheries experimental stations for collecting the specimens, and Drs N. J.
Olsen, Danish Veterinary Laboratory and B. H. Dannevig, National Veterinary Institute, Norway for kindly providing the ASK cell line and ISAV strain Glesvaer/2/90 for us.

\section{References}

1) World Organization for Animal Health (OIE) (2008): In "Aquatic Animal Health Code" 11th edition. World Organization for Animal Health (OIE), Paris, 307 p. 2) Lovely, J. E., B. H. Dannevig, K. Falk, L. Hutchin, A. M. MacKinnon, K. J. Melville, E. Rimstad and S. G. Griffiths (1999): Dis. Aquat. Org., 35, 145-148. 3) Raynard, R. S., A. G. Murray and A. Gregory (2001): Dis. Aquat. Org., 46, 93-100. 4) Bouchard, D. A., K. Brockway, C. Giray, W. Keleher and P. L. Merrill (2001): Bull. Eur. Ass. Fish Pathol. 21, 86-88. 5) Kibenge, F. S. B., O. N. Gárate, G. Johnson, R. Arriagada, M. J. T. Kibenge and D. Wadowska (2001): Dis. Aquat. Org., 45, 9-18. 6) Godoy, M. G., A. Aedo, M. J. Kibenge, D. B. Groman, C. V. Yason, H. Grothusen, A. Lisperguer, M. Calbucura, F. Avendaño, M. Imilán, M. Jarpa and F. S. Kibenge (2008): BMC Vet. Res., 4, 28. 7) Dannevig, B. H. and K. E. Thorud (1999): In "Fish diseases and disorders Vol. 3" (ed. by Woo, P. T. K. and D. W. Bruno). CAB International, Wallingford, U. K, pp. 149-158. 8) T. Hovland, T., A. Nylund, K. Watanabe and C. Endresen (1994): J. Fish Dis., 17, 291-296. 9) Nylund, A., T. Hovland, K. Watanabe and C. Endresen (1995): J. Fish Dis., 18, 135-145. 10) Falk, K., V. Aspehaug, R. Vlasak and C. Endresen (2004): J. Virol., 78, 3063-3071. 11) Mjaaland, S., E. Rimstad, K. Falk and B. H. Dannevig (1997): J. Virol., 71, 7681-7686. 12) Kawaoka, Y., N. J. Cox, O. Haller, S. Hongo, N. Kaverin, H. -D. Klenk, R. A. Lamb, J. McCauley, P. Palese, E. Rimstad and R. G. Webster (2005): In Virus Taxonomy Eight report of the International Committee on Taxonomy Viruses" (ed. by Fauquet C. M., M. A. Mayo, J. Maniloff, U. Desselberger and L. A. Ball). Elsevier Academic Press, New York, pp. 681-693. 13) Nyland, A., S. Alexandersen, J. B. Rolland and P. Jakobsen (1995): J. Aquat. Anim. Health, 7, 236-240. 14) Nylund, A. and P. Jakobsen (1995): J. Fish. Biol. 47: 174-176. 15) Nylund, A., A. M. Kvenseth, B. Krossøy and K. Hodneland (1997): J. Fish Dis., 20, 275-279. 16) Rolland, J. B. and J. R. Winton (2003): J. Fish Dis., 26, 511-520. 17) Dannevig, B. H., K. Falk and E. Namork (1995): J. Gen. Virol., 76, 1353-1359. 18) Devold, M., B. Krossøy, V. Aspehaug and A. Nylund (2000): Dis. Aquat. Org., 40, 9-18. 19) World Organization for Animal Health (OIE) (2006): In "Manual of Diagnostic Tests for Aquatic Animal Health" 5th edition. World Organization for Animal Health (OIE), Paris, 469 p. 20) Yoshimizu, M., T. Nomura, Y. Ezura and T. Kimura (1993): Fish. Res., 17, 163-173. 21) Kasai, H., Nomura, T., and M. Yoshimizu (2004): In "Proceedings of the Japan-Korea joint seminar on fisheries sciences", pp. 142-147. 22) Yoshimizu, M., T. Kimura and J. R. Winton (1985): Prog. Fish. Cult., 47, 199-200. 23) Bruchhof, B., O. Marquardt and P. J. Enzmann (1995): J. Virol. Methods, 55, 111-119. 24) Heppell, J., L. Berthiaume, E. Tarrab, J. Lecomte and M. Arella (1992): J. Gen. Virol. 73, 2863-2870. 25) Melville, K. J. and S. G. Griffiths (1999): Dis. Aquat. Org., 38, 231-234. 26) Rolland, J. B., D. Bouchard, J. Coll and J. R. Winton (2005): J. Vet. Diagn. Invest., 17, 151-157. 